Papers and Proceedings of the Royal Society of Tasmania, Volume 113, 1979

(ns, received 4.12 .1978 )

\title{
LATE PLEISTOCENE BONE DEPOSITS FROM A CAVE IN THE FLORENT INE VALLEY, TASMANIA
}

by A. Goede and P. Murray

University of Tasmania and Tasmanian Museum

(with six text figures, one table and five plates)

\section{ABSTRACT}

GOEDE, A. and MURRAY, P., 1979 (20 vii): Late Pleistocene bone deposits from a cave in the Florentine Valley, Tasmania. Pap. Proc. R. Soc. Tasm., 113: 39-52 (incl. five plates). ISSN 0080-4703. Department of Geography, University of Tasmania, Hobart, Tasmania and Tasmanian Museum and Art Gallery, Hobart, Tasmania, Australia.

A limestone shelter cave in the Florentine valley, south-central Tasmania, has yielded vertebrate remains. Two of the three sites excavated have yielded evidence of the presence of elements of the pleistocene megafauna. The morphology and stratigraphy of the cave is described. Pleistocene deposits are shown to consist of two units. A lower unit laid down by water with an admixture of roof fall and an upper unit of angular limestone detritus derived from physical weathering within the cave entrance. C-14 dating indicates a late pleistocene age for material collected from one of the sites. Its stratigraphic relationship to the other sites is discussed.

\section{INTRODUCTION}

Palaeontological and geomorphological investigations were carried out in Titans Shelter, a limestone shelter cave, in 1976 and 1977 . It is located just below the crest of a limestone hill at an elevation of $400 \mathrm{~m}$ within the broad valley of the Florentine River some $23 \mathrm{~km}$ north-northwest of Maydena (146 $\left.28^{\prime} 9^{\prime \prime} \mathrm{E}, 42^{\circ} 34^{\prime} 57^{\prime \prime} \mathrm{S}\right)$. It is approximately $1.4 \mathrm{~km}$ south-southwest of Beginners Luck Cave where the authors have previously investigated a P1eistocene archaeological bone site (Goede and Murray, 1977) (figure 1).

Excavations were made at three sites (E, F and G) and a11 have yielded vertebrate remains (figure 2). Site $G$ proved the most rewarding containing a number of extinct species which included Macropus titan, Protemodon sp., Sthenumus sp., Sarcophilus sp. and an unidentified diprotodontid. The bones at this site have been extensively chewed and fragmented suggesting derivation from a carnivore's den - probably occupied by Sarcophizus. The small passage from which the material entered the chamber is at present inhabited by Sareophizus harrissiz as evidenced by fresh coprolites found during some of our visits.

\section{CAVE DESCRIPTION}

The cave has developed in well-bedded Ordovician 1imestone (Gordon Limestone) locally dipping south-west at an angle of some $25^{\circ}$. The cave is shown in $\mathrm{p} 1 \mathrm{an}$ in figure 2 and in longitudinal section in figure 3 . The cave mouth is situated in a steep anti-dip slope close to the crest of the hill and consists of a wide, low opening ( $5 \times 2.2 \mathrm{~m}$ ) facing north-east (plates 1 and 2$)$. The cave floor slopes steeply inwards at a maximum angle of $35^{\circ}$ from the crest of a natural rampart approximately three metres outside the roof line of the entrance. The roof of the entrance chamber looks unstable and descends in a series of steps formed by roof fall parallel to the bedding. Despite the unstable appearance of the roof there has been little recent roof fall as evidenced by joint-aligned rows of spongy stalactitic formations covered by algal growth. 


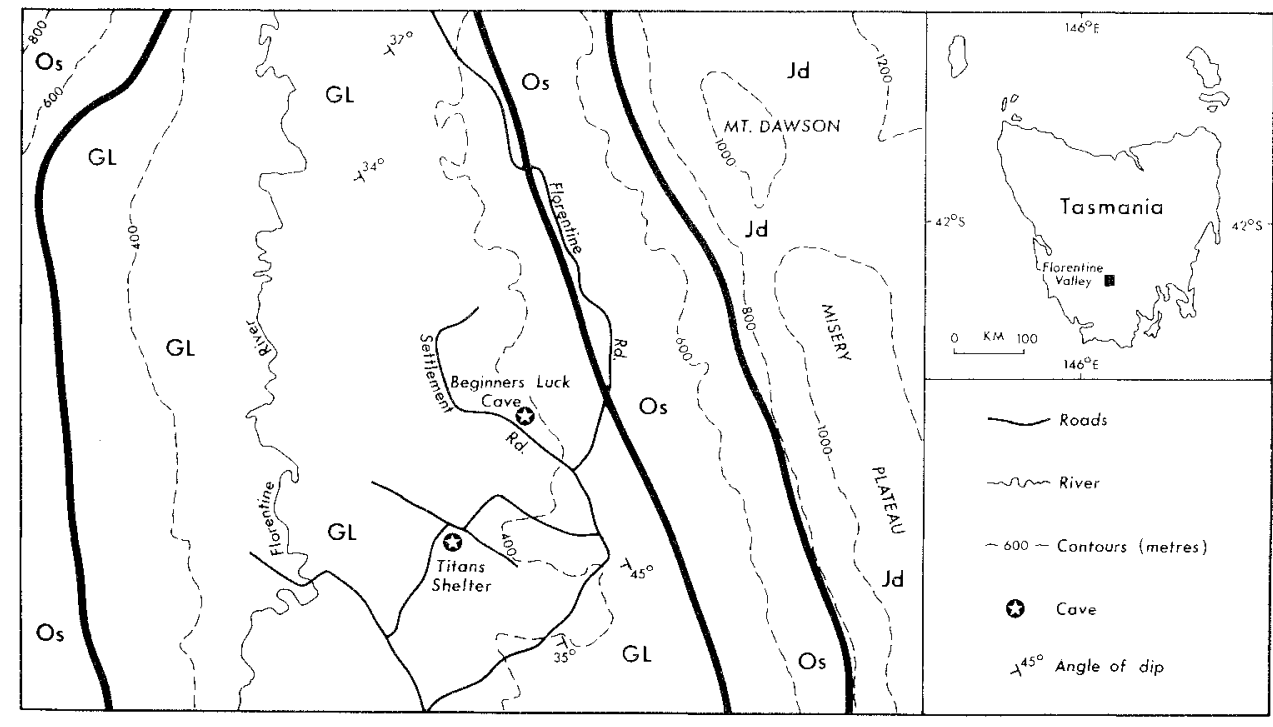

$\mathrm{GL}$ - Gordon Limestone (Ordovician) Os - Other sedimentary rocks Jd - Dolerite (Jurassic)
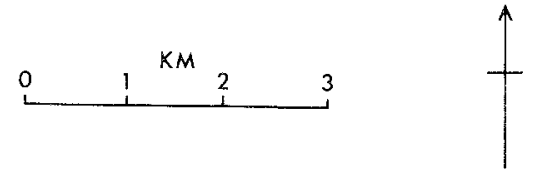

FIG. 1.- Locality and lithological map of part of the Florentine Valley (lithology after Corbett 1963).

The floor is partly covered by slabs of roof fall - the largest being $2.0 \times 2.3 \times$ $0.35 \mathrm{~m}$. These are partly imbedded in a dull yellowish brown (10 YR/4/3) (Standard Soil Color Chart 1965) cave earth mixed with an abundance of smaller limestone fragments and containing significant amounts of charcoal and organic matter. Much of the surface charcoal was derived from burning of slash in the summer of 1975-76 following clearfe11ing.

The entrance chamber has maximum dimensions of $8 \times 9 \mathrm{~m}$ with a maximum ceiling height of $2.3 \mathrm{~m}$. Along the south-western wall approximately $40 \mathrm{~cm}$ below the ceiling a wide, low-roofed extension slopes downward at an angle of $20^{\circ}$ becoming too tight for human penetration after about three metres. It has a bedrock ceiling and a floor consisting of clastic sediments.

At the lowest point of the entrance chamber the roof steps down to a point where large roof fall originally blocked further access. A small opening against the southwestern wall was enlarged to provide entry to a second chamber. 
A. Goede and P. Murray

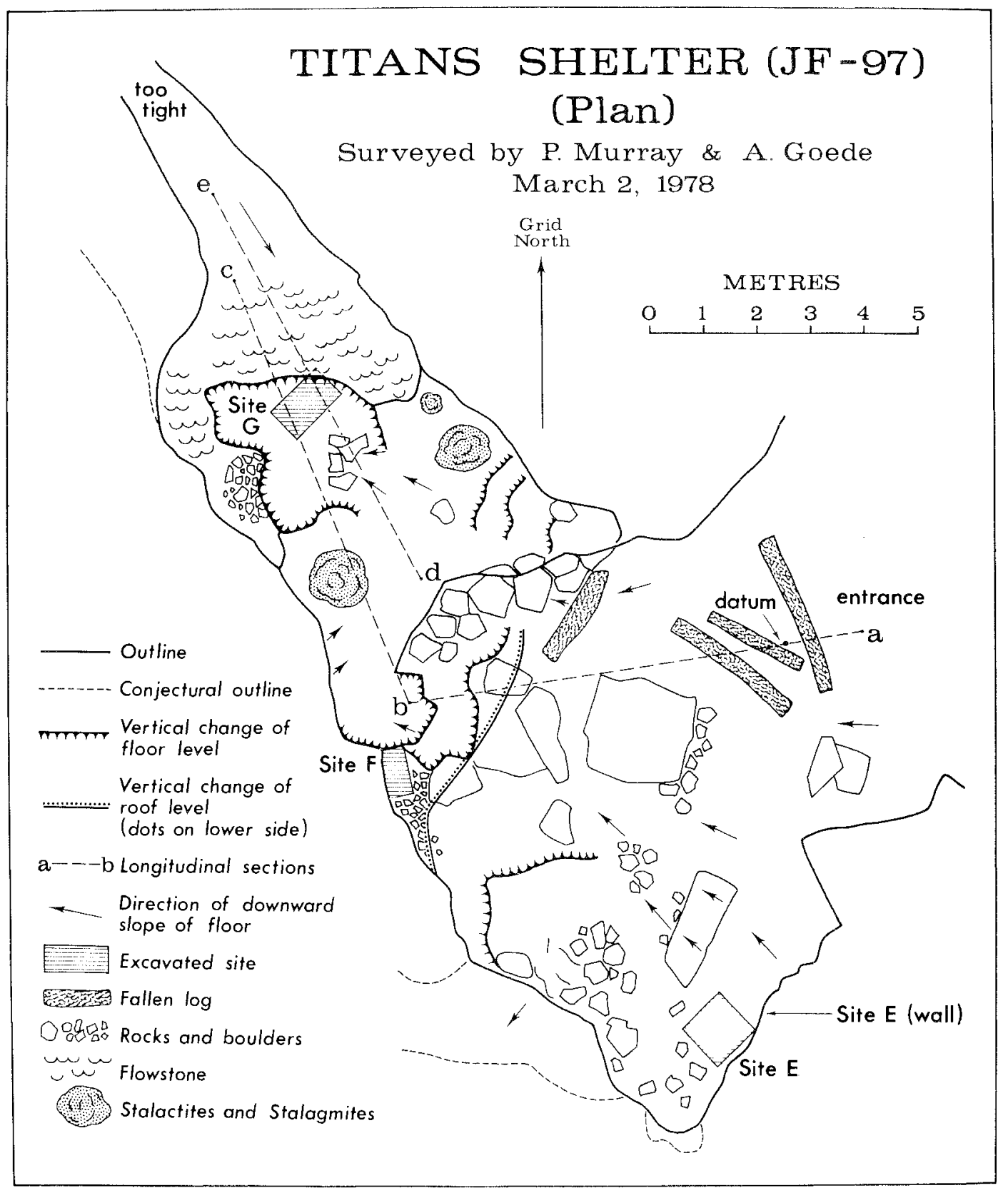

FIG. 2.- Plan survey of Titans Shelter. 


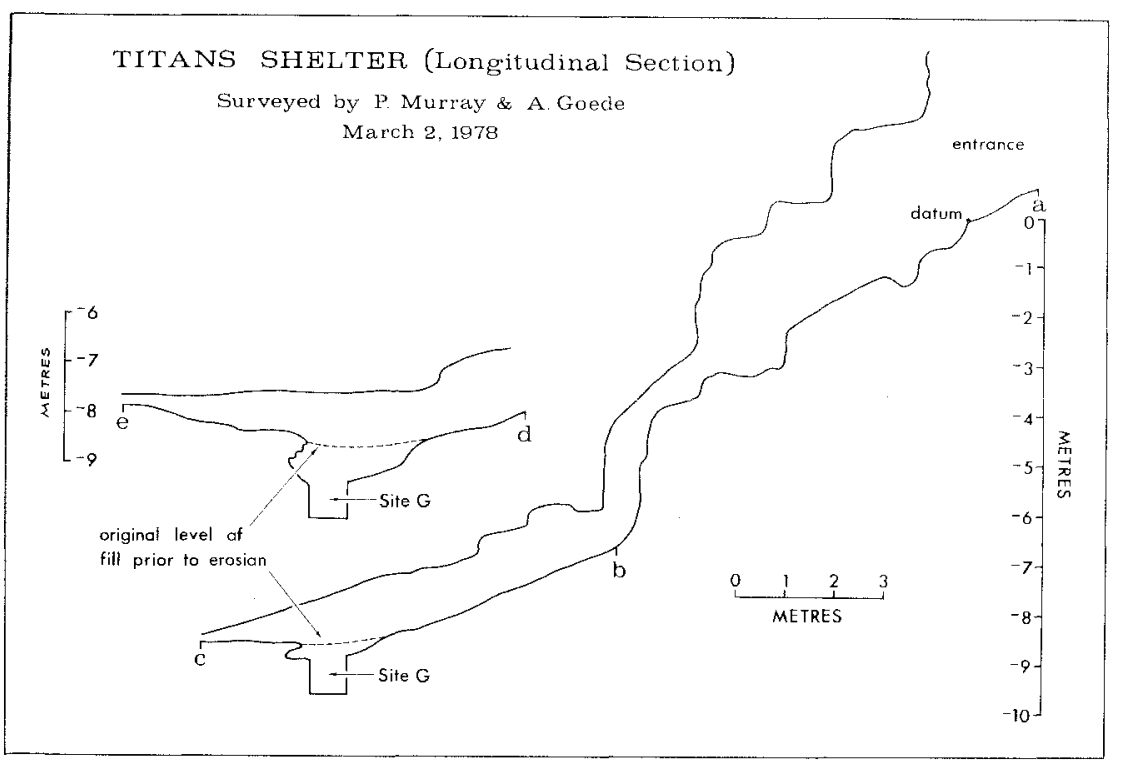

FIG. 3.- Longitudinal section of Titans Shelter.

This chamber is six metres long and up to five metres wide with the floor sloping towards a low point near the north-western extremity. Here, prior to excavation of site $G$, a circular pit approximately one metre deep and with a maximum diameter of $60 \mathrm{~cm}$ had been eroded in the dissected cave fill making up the floor.

At the north-western extremity of the chamber the floor rises again and a flowstone covered slope leads to a low tunnel which soon becomes too tight to allow further exploration. A draught is present possibly indicating another connection with the surface.

\section{EXCAVATION SITES AND ASSOCIATED SEDIMENTS}

Three sites were excavated within the cave, two in the entrance chamber and one in the second chamber.

Site $E$ was located below the south-eastern wall of the entrance chamber (figure 2). In the lower wall above the level of the pit and a little to the north-east some bones and bone fragments were exposed in remnant cave fill containing abundant angular limestone fragments. In the upper $20 \mathrm{~cm}$ there is a sparse dull yellowish brown (10 YR/5/4) matrix while the lower $20 \mathrm{~cm}$ has an openwork texture. The rock fragments generally range from a few $\mathrm{mm}$ to $10 \mathrm{~cm}$ in diameter with a modal range of $2-4 \mathrm{~cm}$. Occasional larger fragments up to $30 \mathrm{~cm}$ are present. This site is referred to as Site E (wa11) in figure 2. Site $E$ was selected because of its proximity to this wall exposure and also because it was one of the few areas in the entrance chamber where large blocks of limestone were absent from the surface. Excavation of a one metre square area on this sloping site revealed a thin uncompacted surface layer of dull 

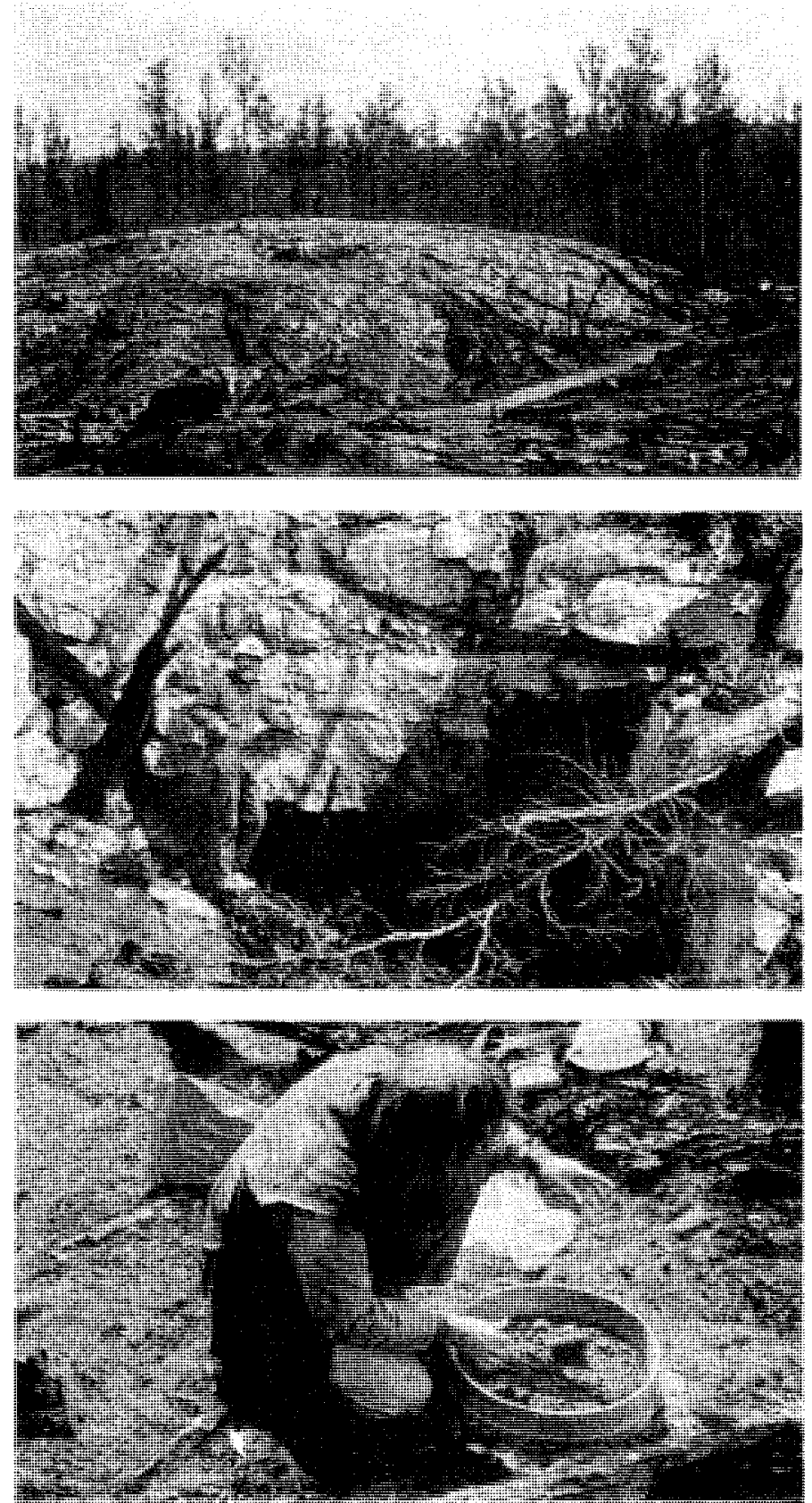

PLATE 1 (top).- View of limestone hill with entrance to Titans Shelter visible below crest.

PLATE 2.- Entrance to Titans Shelter.

PLATE 3 (bottom).- Seiving for bone fragments outside the cave entrance. 


\section{MIISy Limestone}

$\because$ Lower unit (alluvial fan deposits)

Papper unit (stony colluvial fill)

Recent colluvial veneer

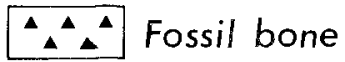

[TT] Dripstone \& flowstone

- ${ }^{14} \mathrm{C}$ dated charcoal

A
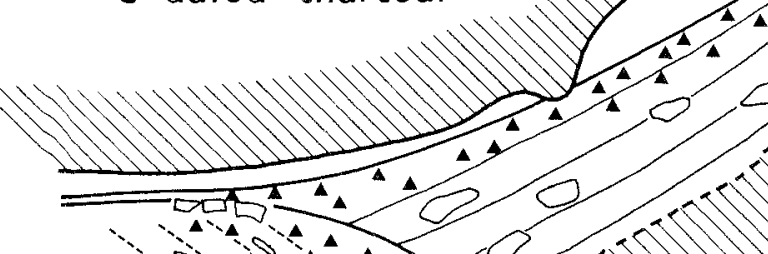

B
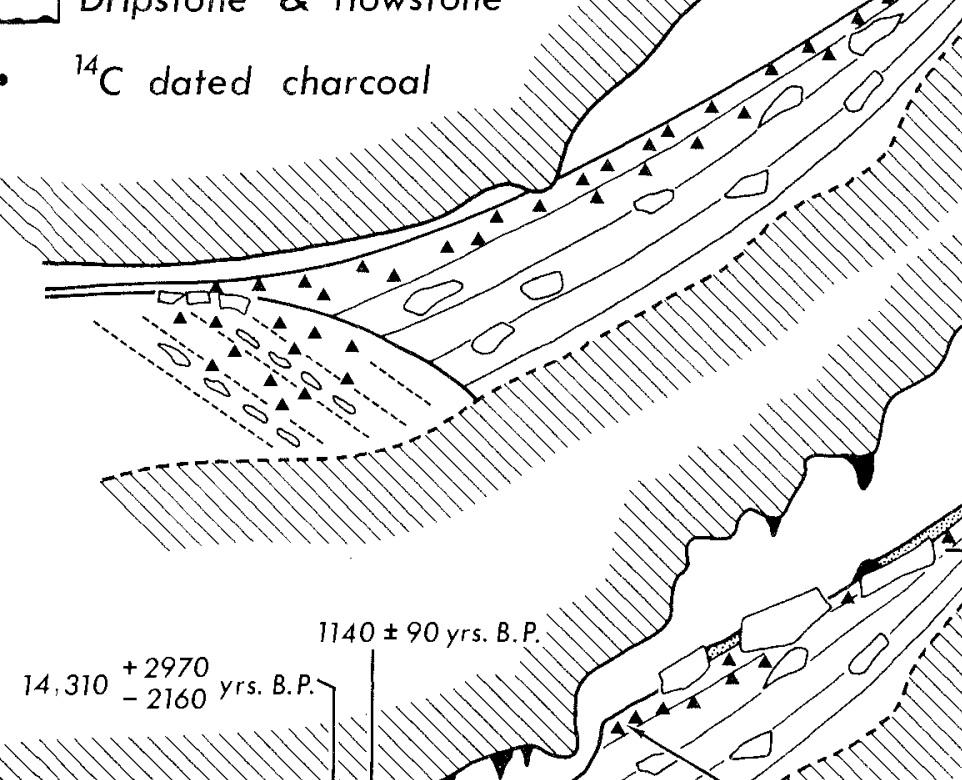

Site $E$

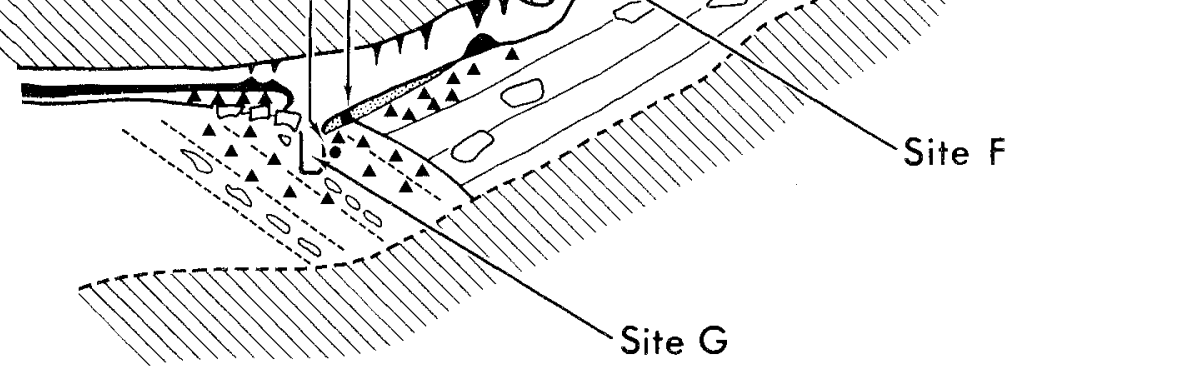

FIG. 4.- Diagrammatic evolutionary sequence of depositional and erosional phases. $A$, end of Pleistocene. B, present day. 
yellowish brown (10 YR/5/3) stony earth thickening downslope and locally containing numerous smal1 bones. There was a steeply dipping contact with marked erosional un-. conformity between it and the underlying sediments. These sediments form a continuous sediment body with the E wall sediments but are stratigraphically lower in the sequence. They consist of a loosely packed rock rubble in a partial matrix of bright brown $(7.5 \mathrm{YR} / 5 / 6)$ earth. Voids are common and there is abundant evidence of subsequent deposition of spongy calcium carbonate by percolating water. The stone size tends to increase towards the base of the exposure with nany fragments from 5 to 20 $\mathrm{cm}$ in diameter.

The sediments contained a number of bone fragments, many of them broken. A single fragment of angular grey quartzite was also discovered (dimensions $49.0 \times 56.5$ $\mathrm{mm}$ ). This represents the only piece of non-limestone rock found so far in any of the sediments examined in this cave. Although it is tempting to suggest that it was brought to the cave by man it shows no clear evidence of being an artifact. Excavation of site $E$ was abandoned because of the decreasing bone content with depth and increasing problems with large blocks of roof fall.

Site $F$ consists of a remnant of undissected cave fill preserved against the west wal1 of the entrance chamber near its lowest point (figures 2 and 4). The deposit consists of an accumulation of limestone fragments ranging in size from angular chips a few $\mathrm{mm}$ in diameter to fragments up to $15 \mathrm{~cm}$. The modal size range is approximately 1 to $3 \mathrm{~cm}$. In the upper part of the deposit the fragments are contained in a sparse matrix of reddish brown ( $5 \mathrm{YR} / 4 / 6)$ clay rich sediment but downwards this grades into an openwork accumulation of angular rock fragments frequently coated with spongy calcium carbonate. The exposure shows at least one metre of sediments of which the top $40 \mathrm{~cm}$ are rich in fossil bone and have been excavated. Cementation of the deposit is quite variable ranging from strongly cemented to loose and friable.

Site $G$ is located at the lowest point of the cave and has been briefly described in an earlier paper (Goede, Murray and Harmon 1978). Prior to excavation it consisted of a circular erosion pit approximately one metre deep and with a maximum diameter of $60 \mathrm{~cm}$. The exposure of numerous small bone fragments in the sides of the pit prompted selection of the site for excavation. The pit was itself located in the floor of a larger erosional depression the outline of which is clearly shown in figure 2 as a vertical change in floor level. The sedimentary sequence is partially capped by flowstone deposition from water entering the chamber from the north-west (figures 2 and 4 ).

The upper unit of the underlying sediments is up to $70 \mathrm{~cm}$ thick and is best exposed to the west of the site and above the level at which excavation started. The deposit is strongly cemented and consists of limestone fragments from a few $\mathrm{mm}$ to 30 $\mathrm{cm}$ in diameter with a modal size range from 2 to $10 \mathrm{~cm}$. There is a sparse matrix of poorly-sorted, dul1 yellow orange $(10 \mathrm{YR} / 6 / 4)$ sediments containing significant amounts of fragmented bone. There is an erosional gap at floor level which separates it from the lower unit exposed in the pit.

To the north of the pit the upper unit rests on the lower one but the two are separated by a layer of limestone slabs approximately $30 \mathrm{~cm}$ thick produced by roof fa11. The upper unit is poorly exposed here due partly to heavy post depositional incrustation of carbonate and partly to subsequent excavation of animal burrows below the flowstone cap. There appears to be a higher proportion of matrix, yellowish brown $(10 \mathrm{YR} / 5 / 6)$ in colour, and a1so containing bone fragments.

The overall slope of the surface of the upper unit indicates that the sediments originated from the present entrance. This unit represents the last majcr phase of clastic deposition in the cave and the sediments are similar to those exposed at sites $\mathrm{E}$ and F with which they are correlated. The erosional depression around site G 
has been excavated largely within the upper unit, the material having apparently been removed through the erosional gap between it and the lower unit.

The lower unit consists of at least $90 \mathrm{~cm}$ of brown to bright brown $(7.5 \mathrm{YR} / 4 / 6$ to $5 / 6$ ) cave earth with a significantly lower stone content than the upper unit. This material was originally exposed in the walls of the pit which was excavated to form a flat-floored rectangular excavation with dimensions of $75 \times 120 \mathrm{~cm}$ and with depth varying from 75 to $95 \mathrm{~cm}$ due to the slope of the floor. The deposit is rich in small bone fragments in a state of preservation varying from very good to soft and crumbly. The nature of the bone fragments, to be discussed later, indicates that the material originated from a carnivore's den (probably Sarcophilus).

The sediments show poorly developed bedding dipping towards the south-east with apparent angles of dip of $25^{\circ}-35^{\circ}$. A similar depositional slope is indicated by a roof fall horizon. In contrast to the overlying bed the sediments have been derived from the constricted passage entering the chamber from the north-west. Their nature indicates deposition by slow moving water in the form of a fan with intermittent roof fall contributing. The sediments are locally penetrated by modern roots several of which had to be cut during excavation.

Charcoal collected from the deposit from the south-eastern wall of the excavation at a depth of between 58 and $75 \mathrm{~cm}$ below the surface was carefully inspected for possible modern root contamination and pretreated prior to dating with boiling $2 \mathrm{~N}$ HC1 solution. The age was determined as $14,310 \pm 2970$ years BP (GaK-6875).

The sections (figure 4) show that on the north-western side of the pit the older sediments are overlain by a low mound of much more recent reddish brown (5 YR/4/6) sediment which accunulated as a result of animal burrowing (probably by Vombatus ursinus in the upper unit. This is clearly a recent event postdating the dissection of the upper unit.

On the south-eastern side of the pit the sediments of the lower unit are overlain by a thin $(<10 \mathrm{~cm})$ layer of loose charcoal rich sediment which accumulated as a thin mantle after dissection of the older deposits. Charcoal from this layer was pretreated with boiling $2 \mathrm{~N}$ HCl solution and yielded a late Holocene date of $1140 \pm 90$ years BP $($ GaK-6874).

\section{FAUNAL ANALYSIS}

Samples of fossil vertebrate remains were recovered from three sites in Titans Shelter. Site E yielded insufficient material for statistical analysis. Sites $F$ and $G$ both contained numerous whole and fragmentary bones in sufficient quantity to permit comparison with other Florentine Valley cave deposits.

Site E: A clear faunal demarcation between Holocene and Pleistocene sediments was apparent in this test excavation. The upper, probably mid to Late Holocene stratum contains only small mammal remains which represent regurgitated predatory bird pellets. The marsupial mouse (Antechinus swainsoni) and the long-tailed rat (Pseudomys higginsi) are the dominant elements in the deposit. A single canine of a Peramelid (probably Peramezes) was also recovered.

The lower brown stratum contained Thylogale bizzardiem, Macropus rufogriseus and Dasyums viverrinus.

Site $E$ : A total of 659 specimens of fossil bone was excavated from a small area of less than $.5 \mathrm{~m}^{2}$ excavated to an average depth of $25 \mathrm{~cm}$. About two-thirds of these remains were identifiable to genus. Nearly 10 per cent of the sample was composed of 
unbroken long bones (p1ate 4).

The material shows evidence of both pre and post depositional alterations by predators and rodents. Tooth marks attributable to marsupial carnivores appear on four per cent of the specimens (figure 5). Eroded compact bone surfaces suggest that some of the fragments may have passed through the digestive system of a carnivorous anima 1. These comprise another four per cent of the sample. Six per cent of the remains consist of small fragments of 1 ong bones that appear to be the result of chewing. In addition, a few bones (1\%) have paired, narrow grooves running perpendicular

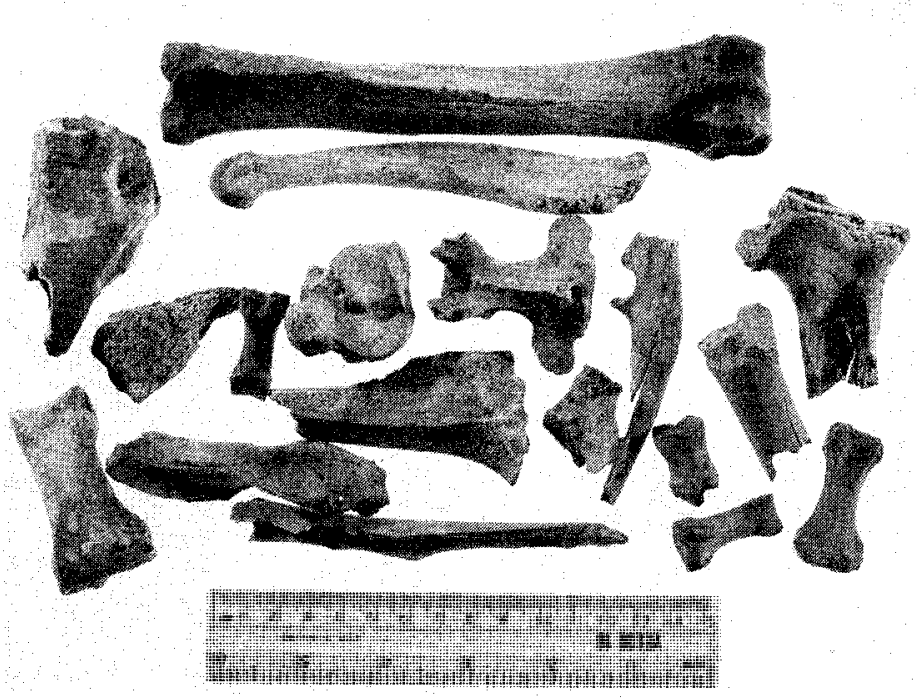

PLATE 4. - Sample of bone material collected from site F. to the long axis of the bone or crests on bones. These grooves closely approximate the dimensions of the occlusal surfaces of Mastacomys fuscus incisors.

The broken bone fragments in site $F$ fall primarily into four shape categories: oblique $(27 \%)$ transverse $(35 \%)$ longitudinal fractures $(27.5 \%)$ and spiral fractures (3\%). The 1ongitudinal fractures appear to be the result of natural weathering processes. Experiments by Miller (1975) suggest that freezing, thawing and drying of fresh bone results in longitudinal cracks that extend into the medullary cavity. Many of the transverse cracks a1so appear to be due to postmortem exposure to extremes of atmospheric conditions. Oblique and spiral fractures probably occurred while the bone was relatively fresh. The presence of collagen in the bone facilitates this type of damage when shearing forces are applied or when a bone is struck solidly with a heavy object. In site $F$ this could be due primarily to roof fall and secondarily to the activity of carnivores.

Site $F$ contained seven mammal and one bird species (table 1 ). The remains of a falcon (Falco sp.) and the unusually large number of Dasyurus viverrinus remains (120 elements) suggest that ow 1 s employed the she1ter as a roost. Nineteen very large macropodid elements have been assigned to Macropus titan. A single metatarsal IV of Sthenurus sp. was also recovered. Macropus rufogriseus is the most common species from site $\mathrm{F}$, comprising $44 \%$ of identifiable remains. Thy Zogale billardieri and Macropus titan remains were less common (respectively $7 \%$ and $5 \%$ ). Sthenums is comparatively rare.

The overall representation of skeletal remains shows an expected predominance of axial elements $(18 \%)$, poor representation of the cranium $(3.1 \%)$ and good representation of mandibles $(9.1 \%)$. Pes elements were greatly over represented in the sample $(21 \%)$. 


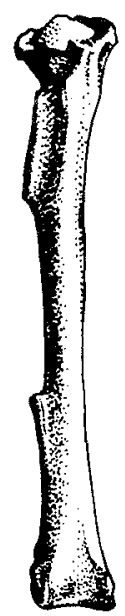

$\boldsymbol{A}$

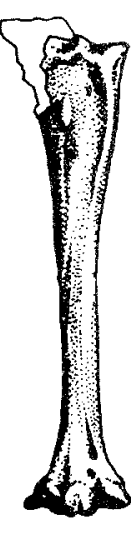

$\boldsymbol{B}$

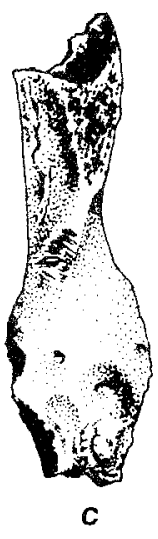

c

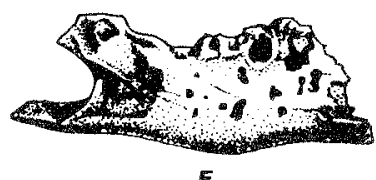

$\boldsymbol{E}$

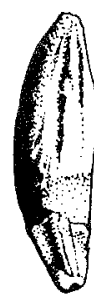

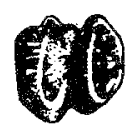

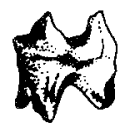

G
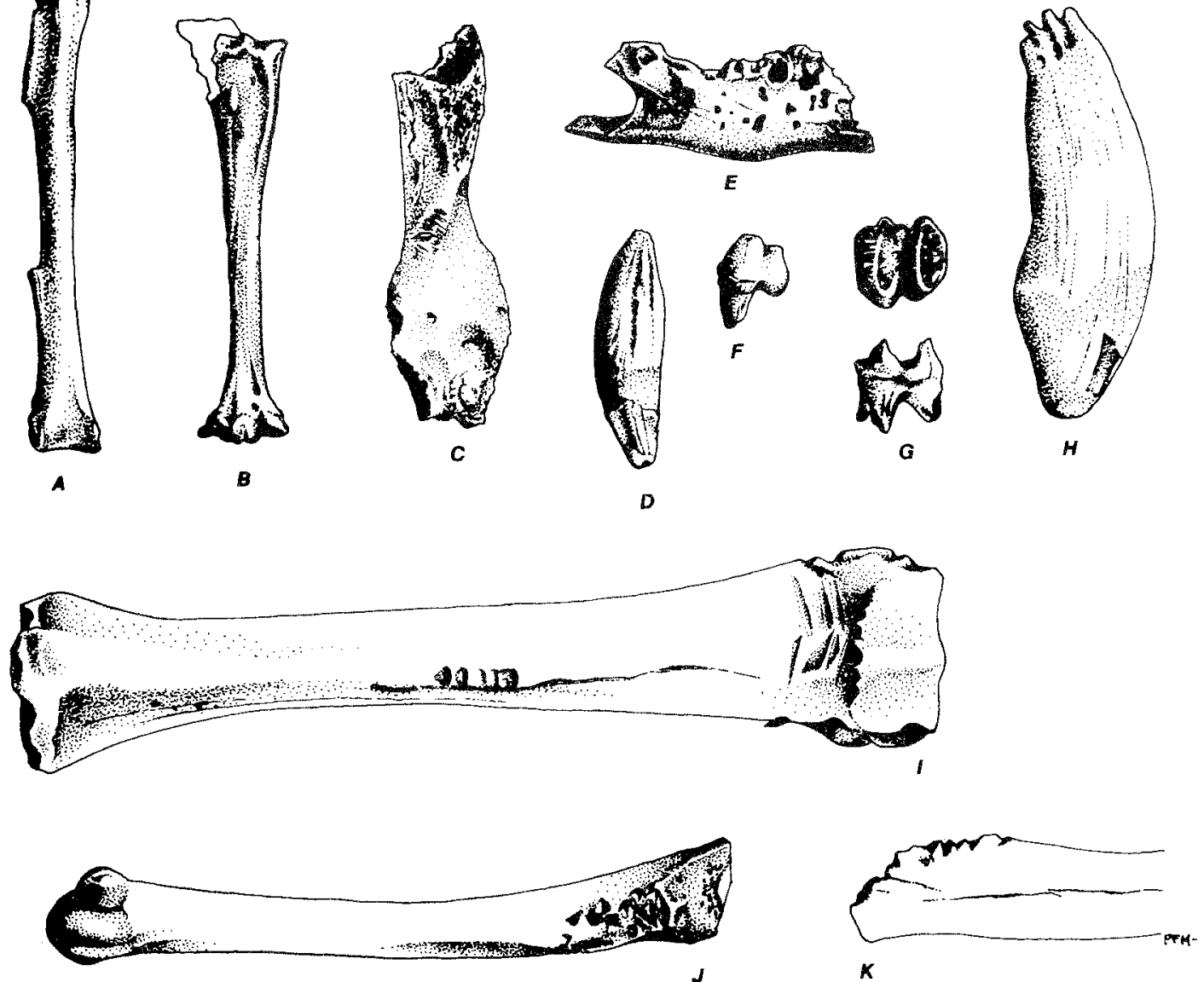

FIG. 5.- Drawing of selected fossil remains from sites $F$ and G. A, tibiotarsus of Falco sp.; B, tarsometatarsus of Falco sp.; C, humerus of Macropus mfogriseus showing tooth marks and damage to distal and proximal ends by gnawing; E, mandible of $M$. mufogmiseus showing attack by snails; D, upper left canine of Sarcophizus sp.; G, left $M^{3}$ of Sthenumus sp. (occlusal and buccal views); H, I ${ }^{l}$ of ?Zygomaturus; I, metatarsal IV of Macropus titan showing marks probably made by a carnivore near distal end and marks made by rodent $(s)$ in the middle of the shaft; $J$, metatarsal. $V$ of Macropus titan showing tooth marks near proximal end; $K$, side view of same.

$\mathrm{A}, \mathrm{B}, \mathrm{C}, \mathrm{E}, \mathrm{I}, \mathrm{J}, \mathrm{K} ; \mathrm{x} 0.57$.

$\mathrm{D}, \mathrm{F} ; \mathrm{x} 0.7$.

$\mathrm{G} \times 0.86$.

$\mathrm{H} \times 0.65$. 


\section{A. Goede and P. Murray}

TABLE 1

SPECIES IDENTIFIED IN TITANS SHELTER

Species

Ealco sp.
Dasyums viverminus
Sarcophizus sp.
Fseudocheims peregrinus
Vombatus ursinus
Sthenurus
Protemodon
Macropus titan
Thylogale billardiem
Macropus rufogmiseus
Pygomaturus
Mastacomys fuscus

Site F

$\begin{array}{lc}\text { Minimum } & \text { Total Remains } \\ \text { Number } & \text { Identified }\end{array}$

Site G

Minimum

Number

1
18
-
-
-
1
-
4
2
5
-
5

Site $G$ : This sample primarily consists of small, apparently chewed bone fragments averaging between 2 and $3 \mathrm{~cm}$ in length. The vast majority of these fragments are technically unidentifiable, although the limited faunal assemblage present in these sites would allow generic assignment on the basis of element size alone. Identification of species and estimates of minimum numbers of individuals are based entirely on isolated teeth and jaw fragments containing teeth (table 1 ).

Site $G$ contains more species than Site $F$, but this is probably due to the much larger sample obtained from this location. The total number of fragments exceeds 5000. A representative sample of site G material consisting of 215 specimens was measured by placing each piece in one of seven two-centimetre categories. This was compared with the Site $F$ sample (figure 6).

In site $G$ the number of fragments in the size categories of between 8 and greater than $12 \mathrm{~cm}$ is practically nil. In site $\mathrm{F}$ there is at least a small representation in each of these larger categories (figure 6 , plates 4 and 5). A $x^{2}$ test suggests that the differences in size distribution of bone fragments at the two sites is highly significant $\left(\chi^{2}=50.13, v=4, p<.001\right)$.

The most likely explanation for the difference in size of fragments is that site $G$ represents water sorted and transported material. It seems very likely that the initial assemblage of fossil material represented only in part at site $G$ is a large deposit. Unfortunately, the passage leading to its probable source is too narrow to negotiate.

\section{PALAEOECOLOGY}

The modern Florentine Valley fauna consists of species known to inhabit wet sclerophy11 and rainforest biomes throughout Tasmania. Samples of fauna from Late Holocene deposits in the valley contain the remains of Omithorhynchus, Tachyglossus, Antechinus swainsoni, Dasyumus maculatus, Sarcophilus hamisii, Thylacinus cynocephalus (now presumed extinct), Perameles gunit, Vombatus ursinus, Potorous tridactylus, Thylogale billardieri, Macropus rufogriseus, Pseudocheirus peregrinus and Pseudomys higginsi. Despite the relatively large samples of fossil material from sites $F$ and $G$, a substantial number of these species are not represented. Important absences include the tiger cat (D. maculatus), the marsupial mouse (Antechinus swainsoni), the velvet 


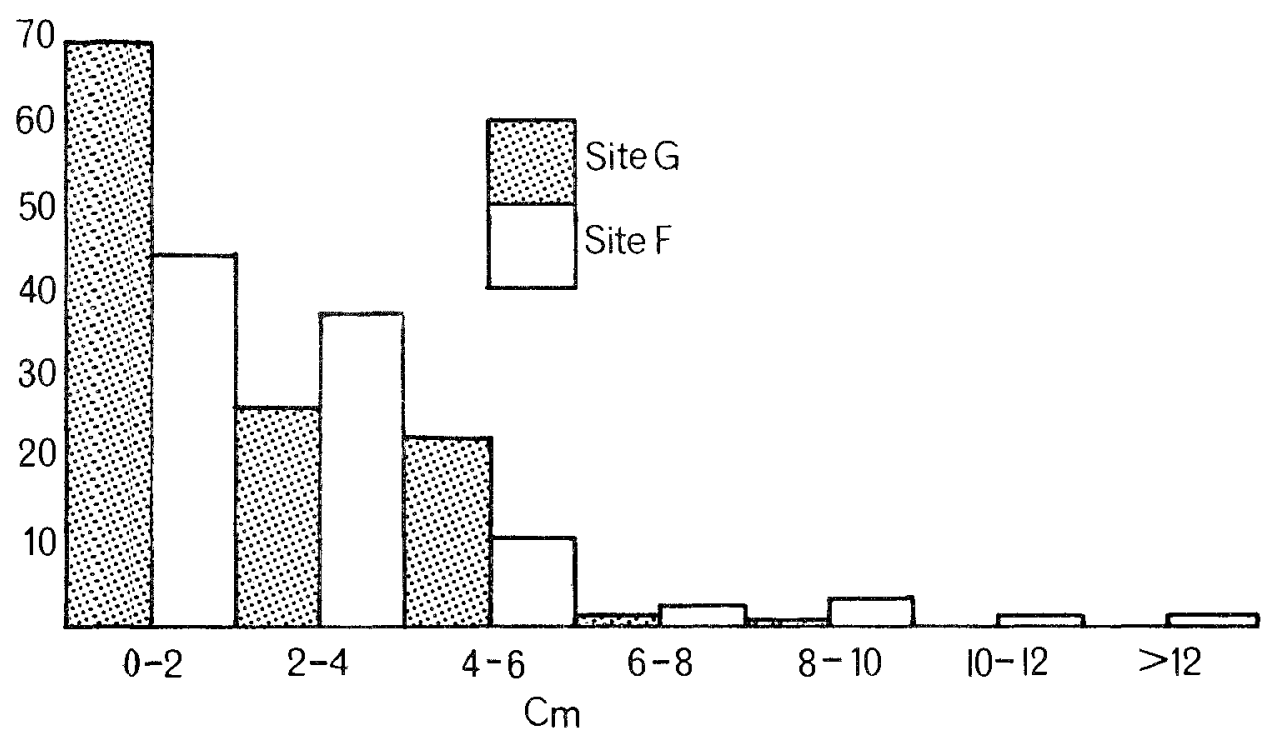

FIG. 6.- Size distribution of bone fragments for sites $G(n=215)$, and site $F(n=659)$.

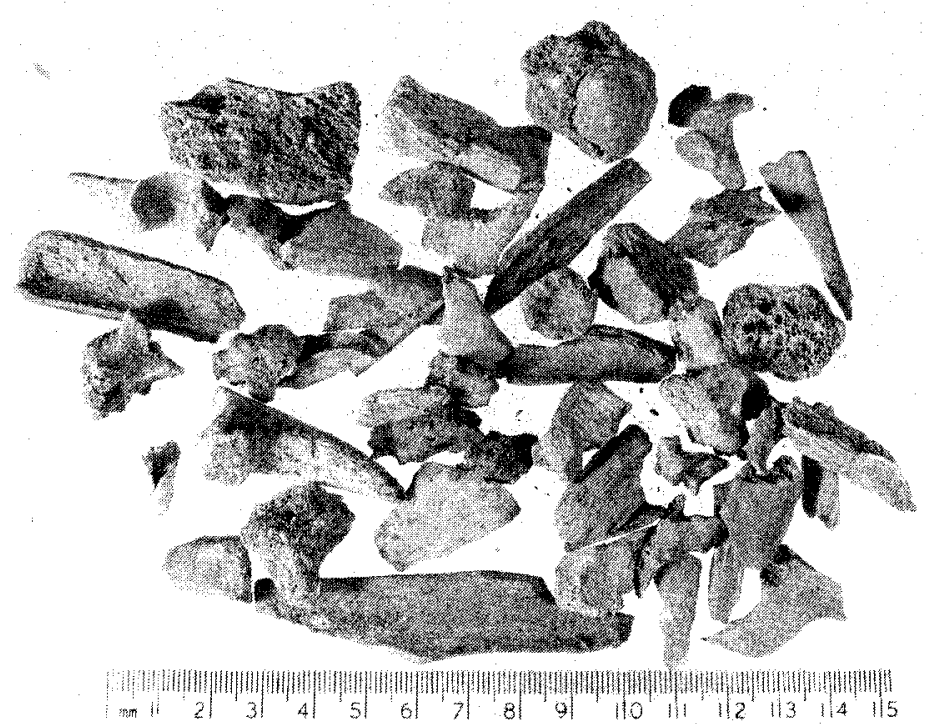

PLATE 5.- Sample of bone material collected from Site G. furred rat (R. lutreolus) and the potoroo (Potorous tridactylus). These mammals are typical fern gully and rainforest edge species. However, certain constituents of the fossil fauna suggest the presence of some type of arborescent vegetation and/or scrub, particularly Pseudocheirus, Sthenurus and Thy Zogale. The large kangaroo, $M$. titan was probably similar to the modern grey kangaroo in preferring open sclerophy11 and woodland savanna habitat. Mastacomys fuscus is a relict species in Tasmania. Its distribution during the Late Pleistocene was greatly expanded, while Rattus lutreolus and Pseudomys spp. appear to have been very rare. $M$. fuscus may have preferred 


\section{A. Goede and P. Murray}

open sedge and grassland habitats. It is today confined to cool, wet sedgeland and grassland associations. The Titan Shelter assemblage appears to represent an open vegetation type community consisting of some sclerophyl1 forest elements and some low scrub situated within grasslands.

\section{HISTORY AND AGE OF SEDIMENTATION}

The lower unit excavated at site $G$ represents the olclest sediments exposed in the cave. The base is not exposed as it was not possible to deepen the excavation further without digging into collapse material at the base of the pre-existing erosion pit. Unlike the upper unit the provenance of the sediments is from the north-westerly trending passage that continues on from the second chamber. The nature and bedding of the material indicates accumulation by runing water in a low energy environment contemporaneous with intermittent roof fall. A very short distance of transport is suggested by the nature of the bone content.

Extinct fauna is represented throughout the excavated depth. Charcoal is not common and at only one place occurred in sufficient quantity to permit C14 dating $(14,310+2970$ years BP). The large standard error is due to the small size of the sample. The date indicates a late pleistocene age. This date has been quoted by Goede, Murray and Harmon (1978) as evidence of Late Pleistocene survival of megafauna in the Florentine Valley. However, it cannot be regarded as conclusive evidence. Since the bone content has been reworked the possibility exists that the bone is significantly older than the charcoal with which it is associated.

The upper unit is exposed in the banks above the level of excavation site $G$. The upper horizons of the same unit were examined at sites $E$ (wall), E and $F$ while some of the lower horizons are exposed in the squeeze below site F. Beds with limestone fragments in a sparse matrix alternate with layers of open work fragments. Both bone and matrix seem to be concentrated in the upper horizons but bone is relatively abundant. only at site $E$.

The upper unit appears to have accumulated as a result of gravitational movement downslope of material produced by roof fall and physical weathering. The nature of this deposit suggests cold and probably dry conditions during its formation. It is similar in character to the upper unit described from site P in Beginners Luck Cave (Goede and Murray 1977) and the two deposits may be of similar age. The increase in the content of bone and matrix in the upper horizons may reflect a gradual moderation of climatic conditions.

Unfortunately the unit contains no significant amounts of charcoal that would enable it to be dated. There is no evidence of a significant time gap between the accumulation of the upper and lower units. The upper unit is believed to represent the final phase of Pleistocene deposition prior to the climatic warming which led to the invasion of forests at about 11,500 C14 years BP (Macphail 1975).

It is followed by a long period when erosion by seepage water and deposition of calcium carbonate were the dominant processes. Lack of physical weathering and widespread chemical deposition suggest mild and wet climatic conditions which may have persisted through much of the Holocene. Patchy cementation and local spongy carbonate deposition within the late Pleistocene fills probably also occurred during this time.

Following this episode there was very restricted clastic deposition in late Holocene times. This seems to have been due to the activities of birds and burrowing animals and also to occasional disturbance of the forested surface environment by fire. An episode of fire disturbance is dated at $1140 \pm 90$ years BP. 


\section{CONCLUSIONS}

An unknown thickness of late Pleistocene deposits partially filled Titans Shelter and can be subdivided into two units. The lower unit was deposited by running water with an admixture of rockfall. The fragmentary bone content represents a late

Pleistocene megafauna and suggests surface vegetation conditions rather different from the dense wet sclerophyll forest present in historical times. The C14 date obtained from the unit has been used by Goede, Murray and Harmon (1977) as evidence for the late survival of Pleistocene megafauna in Tasmania but the large standard error of the date combined with the possibility that the bone material. may be older than the sediments in which it occurs must throw some doubt on the evidence.

The younger unit indicates cold and dry conditions with evidence of fauna indicated on $1 y$ in the upper horizons. Accumulation may have occurred under conditions of maximum cold during the last glaciation with some amelioration towards the end.

The balance then swung to a dominance of sediment removal by running water and speleothem formation during the wetter and milder conditions of the Holocene. The most recent events are minor erosion and sedimentation due to biological activity in the cave and fire disturbance of the surface environment.

\section{ACKNOWLEDGEMENTS}

We are grateful for the financial support received by one of us (A. Goede) from the Australian Research Grants Committee towards the cost of field work and C14 dating of the site. Assistance from the University of Tasmania and the Tasmanian Museum is also acknowledged.

We appreciate the help of Denis Charlesworth in the seiving operations on the site and the cleaning of bone material in the 1aboratory. Mrs. Kate Morris drafted the maps and diagrams and the manuscript was typed by Terese Flannagan.

\section{REFERENCES}

Corbett, K.D., 1963: Geology of the Florentine Valley area. U. Tasm. unpub. thes. Goede, A. and Murray, P., 1977: Pleistocene Man in South Central Tasmania: evidence from a cave site in the Florentine valley. Mankind, 11: 2-10. and Harmon, R., 1978: Pleistocene Man and megafauna in Tasmania: dated evidence from cave sites. The Artifact, 3(3): 139-149.

Macphail, M., 1975: Late Pleistocene environments in Tasmania. Search, 6: 295-300. Miller, G.J., 1975: A study of cuts, grooves and other marks on recent and fossil bone: II weathering cracks, fractures, splinters and other similar natural phenomena. In Swanson, E. (Ed.) : LITHIC TECHNOLOGY. Mouton Publishers, The Hague, $251 \mathrm{p}$.

Murray, P. and Goede, A. 1977: Pleistocene vertebrate remains from a cave near Montagu, NW Tasmania. Rec. Q. Vict. Mus., 60: 30 p.

STANDARD SOIL COLOR CHART, 1.965: Fujihira Industry Co. Ltd., Tokyo. 